\title{
Peningkatan Pemahaman Pendidik tentang Sistem Penilaian K-13melalui Penerapan Workshop Internal Berkelanjutan di SMP Negeri 4 Bantimurung Kabupaten Maros
}

\section{Increased Educator Understanding about K-13 Rating System through the Implementation of Continuous Internal Workshop in Junior High School 4 Bantimurung, Maros Regency}

\author{
Burhanuddin $^{1 \%}$ \\ ${ }^{1}$ Pengawas Dinas Pendidikan Kabupaten Maros
}

Received $1^{\text {st }}$ September 2019 / Accepted 24 ${ }^{\text {th }}$ September 2019

\begin{abstract}
ABSTRAK
Penelitian ini adalah penelitian tindakan sekolah yang bertujuan untuk meningkatkan pemahaman pendidik tentang sistem penilaian $K-13$ dengan menerapkan workshop internal berkelanjutan di SMP Negeri 4 Bantimurung Kabupaten Maros. Subjek penelitian ini adalah pendidik SMP Negeri 4 Bantimurung, semester 2 tahun pelajaran 2015/2016 sebanyak 36 orang guru mata pelajaran. Sedangkan yang menjadi objek penelitian adalah pemahaman pendidik tentang sistem penilaian kurikulum 2013. Hasil Penelitian menunjukkan bahwa terjadi peningkatan kesiapan peserta dalam kegiatan workshop di SMP Negeri 4 Bantimurung. Di samping itu juga, terjadi peningkatan kinerja atau pemahaman pendidik dengan kategori minimal baik dalam membuat sistem penilaian hasil pembelajaran melalui pembinaan berupa workshop di SMP Negeri 4 Bantimurung dari siklus I ke siklus II dan mencapai rata-rata 85,28\%. Nilai rata-rata persentase dengan kategori minimal baik telah melampaui target minimal yang telah ditetapkan yakni $85 \%$, artinya $85 \%$ pendidik telah efektif dalam membuat sistem penilaian hasil pembelajaran pada masing-masing aspek.
\end{abstract}

Kata Kunci : Workshop Internal Berkelanjutan

\begin{abstract}
This research is a school action research, which aims to increase the understanding of educators about the K-13 grading system by implementing continous internal workshops in SMP Negeri 4 Bantimurung, Maros Regency. The subject of this research is educator SMP Negeri 4 Bantimurung, 2nd semester of 2015/2016 academic year were 36 subjects. While the object of research is educator's understanding of the 2013 curriculum assessment system. Research results show that an increase in participants' readiness in the workshop activities in SMP Negeri 4 Bantimurung. Besides that, an increase in performance or understanding of educators with a good minimum category in making a learning outcomes assessment system through coaching in the form of workshops at SMP Negeri 4 Bantimurung, from cycle I to cycle II and reached an
\end{abstract}

*Korespondensi:

email:bhur-han@yahoo.co.id 


\section{Efektifitas Anti Inflamasi Daun Mangga (Mangifera Indica) Terhadap Luka Bakar Derajat Dua}

average of $85.28 \%$. The average value of the percentage with a good minimum category has exceeded the minimum target that has been set at $85 \%$, the meaning of $85 \%$ is educators have been effective in creating a learning outcomes assessment system in each aspect.

\section{Keywords: Continuous Internal Workshop}

\section{PENDAHULUAN}

Pendidik merupakan komponen penting yang memegang peranan yang sangat menentukan dalam meningkatkan mutu pendidikan pada satuan pendidikan. Pendidik memiliki tugas utama yaitu menyusun program pembelajaran, menyajikan program pembelajaran, melakukan evaluasi atau penilaian terhadap pelaksanaan program pembelajaran, melakukan analisis hasil pembelajaran, dan menindaklanjuti hasil analisis melaui remedial (perbaikan) dan pengayaan. Berdasarkan lima tugas utama pendidik, maka dalam penelitian tindakan sekolah (PTS) ini yang akan dipertajam untuk dibahas adalah permasalahan penilaian.

Hasil monitoring dan evaluasi pelaksanaan Kurikulum 2013 (K-13) tingkat SMP pada 2014 oleh Kementerian Pendidikan dan Kebudayaan Republik Indonesia, menunjukkan bahwa salah satu kesulitan pendidik dalam mengimplementasikan Kurikulum 2013 adalah dalam melaksanakan penilaian. Sekitar 60\% responden pendidik menyatakan, mereka belum dapat merancang, melaksanakan, mengolah, melaporkan, dan memanfaatkan hasil penilaian dengan baik.

Satuan pendidikan mengalami kesulitan dalam menentukan Kriteria Ketuntasan Minimal (KKM), merumuskan kriteria kenaikan kelas, dan kriteria kelulusan peserta didik. Permasalahan lain yang sering muncul adalah penetapan KKM dan secara teknis menerapkannya pada setiap Kompetensi Dasar (KD) sebagai kompetensi minimal untuk selanjutnya menjadi KKM mata pelajaran. Di samping itu, pendidik mengalami kesulitan dalam menentukan nilai hasil remedial berkaitan dengan KKM.

Data yang didapatkan tersebut oleh Kementerian Pendidikan dan Kebudayaan Republik Indonesia mendorong peneliti untuk melakukan penelitian pada salah satu sekolah binaan yang telah menerapkan kurikulum 2013, yaitu SMP Negeri 4 Bantimurung. Data yang diperoleh melalui analisis angket yang telah diisi oleh pendidik SMP Negeri 4 Bantimurung sebanyak 36 orang menunjukkan bahwa terdapat 22 orang atau $61,11 \%$ yang belum mampu menentukan nilai kognitif, terdapat 24 orang atau $66,57 \%$ yang belum mampu menentukan nilai keterampilan, terdapat 25 orang atau $69,44 \%$ yang belum mampu merumuskan deskripsi hasil penilaian sikap, terdapat 23 orang atau $63,89 \%$ yang belum mampu merumuskan deskripsi hasil penilaian pengetahuan, terdapat 25 orang atau $69,44 \%$ yang belum mampu merumuskan deskripsi hasil penilaian keterampilan, terdapat 27 orang atau 75,00\% yang belum mampu menentukan interval predikat.

Berdasarkan hasil analisis angket tersebut menunjukkan bahwa secara rata-rata terdapat 24 orang atau 66,67\% yang belum memahami dengan baik tentang penilaian yang diterapkan pada K-13. Untuk mengatasi permasalahan tersebut, maka peneliti 
melakukan tindakan dalam bentuk workshop yang ditindaklanjuti dengan pendampingan melalui supervisi akademik, untuk memberikan pemahaman dasar kepada pendidik tentang sistem penilaian dalam K-2013.

\section{METODE PENELITIAN}

Penelitian ini merupakan penelitian tindakan sekolah (PTS), selama 3 bulan di SMP Negeri4 Bantimurung. Pelaksanaan penelitian dibagi menjadi dua siklus, yaitu siklus I dan siklus II. Setiap siklus dibagi empat tahap yaitu tahap persiapan, pelaksanaan tindakan, pengumpulan data, dan analisis data (refleksi). Subjek penelitian ini adalah pendidik SMP Negeri 4 Bantimurung semester 2 tahun pelajaran 2015/2016, sebanyak 36 orang guru mata pelajaran. Objek penelitian adalah pemahaman pendidik tentang sistem penilaian K-13. Variabel dalam PTS ini adalah sistem penilaian K-13 dan workshop internal berkelanjutan.

Rancangan penelitian ini adalah rancangan model Kemmis yang terdiri dari empat langkah, yakni perencanaan, pelaksanaan, observasi dan refleksi (Wardhani, 2007: 45). Adapun alur dalam PTS dapat digambarkan sebagai berikut.

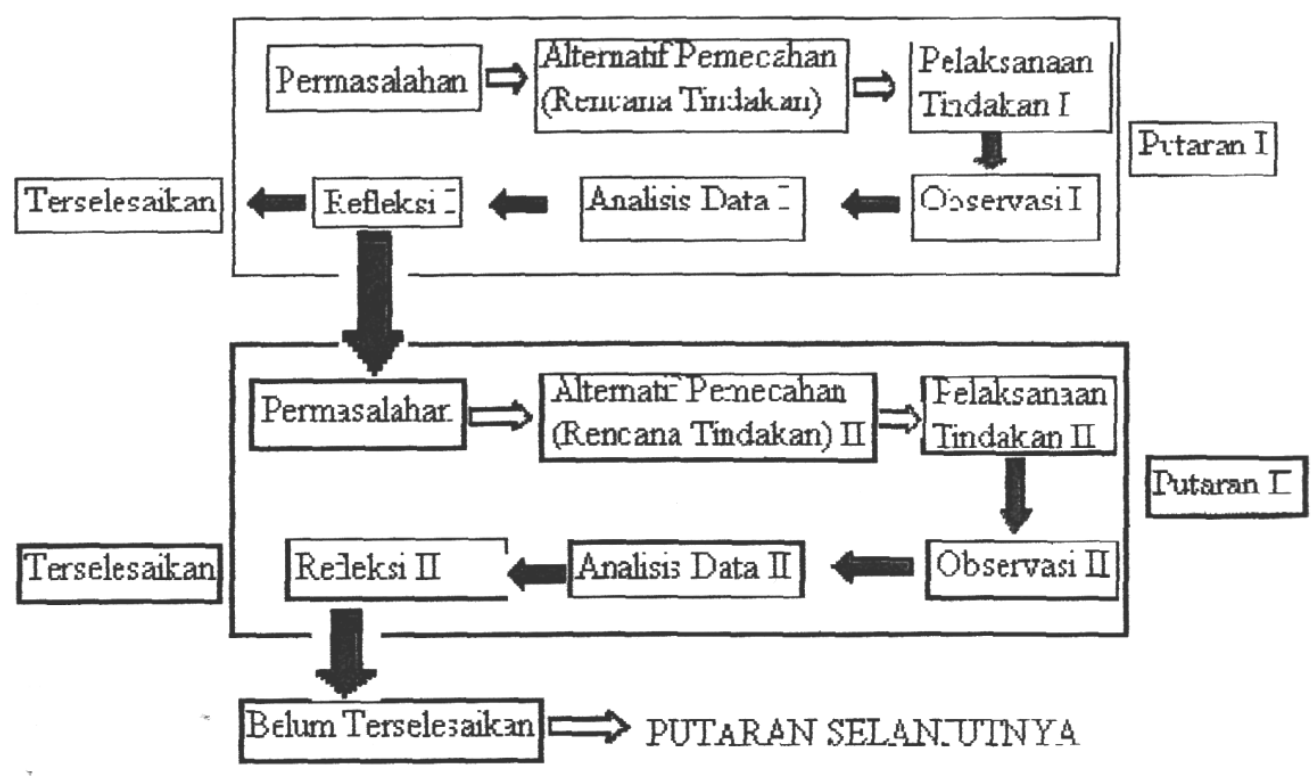

Gambar 1. Skema Penelitian Tindakan Sekolah

\section{Pelaksanaan Siklus I}

\section{Perencanaan}

Beberapa kegiatan yang dilakukan adalah sebagai berikut.

a. Mengumpulkan pendidik melalui undangan kepala sekolah

b. Menyusun jadwal workshop: hari, tanggal, jam dan tempat.

c. Menyiapkan materi workshop

d. Menyiapkan konsumsi untuk workshop.

\section{Pelaksanaan}

a. Hari pertama jam 11.30-17.00 WITA bertempat di SMP Negeri 4 Bantimurung.

b. Hari kedua praktik perumusan/penyusunan penilaian disertai pendampingan. 


\section{Efektifitas Anti Inflamasi Daun Mangga (Mangifera Indica) Terhadap Luka Bakar Derajat Dua}

\section{Observasi}

Pada kegiatan observasi peneliti mengfokuskan perhatian pada hal-hal seperti

a. Kesiapan mental dan fisik pendidik.

b. Kesiapan bahan-bahan yang dibawa pendidik pada saat workshop.

c. Kehadiran pendidik.

Untuk melaksanakan observasi terhadap pelaksanaan dan hasil pemberian tindakan, menggunakan pedoman observasi sebagai berikut.

1) Format Pedoman Observasi Proses Pelaksanaan Workshop

\begin{tabular}{|c|c|c|c|c|c|c|c|c|}
\hline \multirow{2}{*}{ Nama } & \multicolumn{6}{|c|}{ Aspek yang Diamati } \\
\cline { 2 - 9 } & $\begin{array}{c}\text { Kesiapan } \\
\text { mental dan } \\
\text { fisik pendidik }\end{array}$ & \multicolumn{2}{|c|}{$\begin{array}{c}\text { Kesiapan } \\
\text { bahan }\end{array}$} & \multicolumn{2}{|c|}{$\begin{array}{c}\text { Kehadiran } \\
\text { Pendidik }\end{array}$} & \multicolumn{2}{|c|}{$\begin{array}{c}\text { Kesiapan } \\
\text { Laptop }\end{array}$} \\
\hline$\ldots$ & $\mathrm{S}$ & $\mathrm{TS}$ & $\mathrm{S}$ & $\mathrm{TS}$ & $\mathrm{H}$ & $\mathrm{TH}$ & $\mathrm{S}$ & $\mathrm{TS}$ \\
\hline & & & & & & & & \\
\hline & & & & & & & & \\
\hline
\end{tabular}

Keterangan:
$\mathrm{S}=\operatorname{siap}$
$\mathrm{H} \quad=$ hadir
$\mathrm{TS}=$ tidak siap
$\mathrm{TH}=$ tidak hadir

2) Format Pedoman Penilaian Penyusunan/perumusan

\begin{tabular}{|c|l|c|c|c|c|}
\hline \multirow{2}{*}{ No Aspek yang Dinilai } & \multicolumn{1}{|c|}{} & \multicolumn{3}{c|}{ Nilai } \\
\cline { 5 - 6 } & & $\mathbf{1}$ & $\mathbf{2}$ & $\mathbf{3}$ & $\mathbf{4}$ \\
\hline 1. & Pemahaman tentang penilaian sikap & & & & \\
\hline 2. & Pemahaman tentang penilaian pengetahuan & & & & \\
\hline 3. & Pemahaman tentang penilaian keterampilan & & & & \\
\hline 4. & Pemahaman tentang penentuan KKM & & & & \\
\hline 5 & Pemahaman tentang penentuan interval predikat & & & & \\
\hline 6. & Pemahaman tentang rumusan deskripsi sikap & & & & \\
\hline 7 & $\begin{array}{l}\text { Pemahaman tentang rumusan deskripsi } \\
\text { pengetahuan }\end{array}$ & & & & \\
\hline 8 & $\begin{array}{l}\text { Pemahaman tentang rumusan deskripsi } \\
\text { keterampilan }\end{array}$ & & & & \\
\hline 9 & Pemahaman tentang penentun nilai rapor /laporan & & & & \\
\hline 10 & Pemahaman tentang rubrik/pedoman penilaian. & & & & \\
\hline \multicolumn{2}{|l|}{ Jumlah } & & & & \\
\hline
\end{tabular}

Keterangan:

$4(3,50-4,00)=$ sangat paham

$3(2,50-3,49)=$ paham

$2(1,50-2,49)=$ cukup paham

$1(0,01-1,49)=$ tidak paham

$$
\text { Nilai }=\frac{\text { Skor Perolehan }}{\text { Skor Maksimum }} \times 4
$$




\section{Refleksi}

Pada kegiatan refleksi peneliti memperhatikan apa yang menjadi kelemahan atau masalah yang kurang dipahami pendidik yang terkait dengan penilaian yang meliputi penilaian sikap, pengetahuan dan keterampilan. Selain itu juga peneliti juga pemahaman pendidik dalam merumuskan deskripsi penilaian sikap, pengetahuan dan keterampilan yang direkomendasikan kepada wali kelas. Kemampuan merumuskan rubrik penilaian dan pedoman penskoran oleh pendidik. Kelemahan atau kekurangan pada siklus I peneliti membuatkan perencanaan pada siklus II dalam kegiatan workshop.

\section{Pelaksanaan Siklus II}

Pada dasarnya siklus II memiliki prosedur yang sama dengan siklus I, hanya saja diadakan perbaikan pada hal-hal yang dilihat ada kelemahan serta mempertahankan halhal yang sudah berjalan dengan baik. Tidak menutup kemungkinan juga dilakukan modifikasi terhadap hal-hal sudah baik supaya tindakan yang diberikan tidak membosankan.

Teknik analisis data pada penelitian ini yaitu, data yang sudah terkumpul disusun dalam tabel dan dianalisis dengan menentukan nilai/skor tertinggi, nilai/skor terendah, nilai/skor rata-rata dan simpangan baku. Adapun rumus yang digunakan adalah:

$$
\%=\left(\frac{\text { skor perolehan }}{\text { skor maksimal }}\right) \times 100
$$

Teknik kategorisasi yang dimaksudkan adalah skala lima, yang akan digunakan untuk menentukan tingkat kelengkapan perangkat pembelajaran pendidik. Kriteria penggunaan kategorisasi dengan skala lima menurut Nurkancana (1992) terbagi dalam lima kategori sebagai berikut:

Tingkat Penguasaan $90 \%-100 \%$ dikategorikan sangat tinggi.

Tingkat Penguasaan $75 \%-89 \%$ dikategorikan tinggi.

Tingkat Penguasaan $55 \%-74 \%$ dikategorikan sedang.

Tingkat Penguasaan $40 \%-54 \%$ dikategorikan rendah.

Tingkat Penguasaan $0 \%$ - $39 \%$ dikategorikan sangat rendah.

Penelitian ini dikatakan berhasil apabila pemahaman pendidik tentang sistem penilaian K-13 minimal 75\% di SMP Negeri 4 Bantimurng Kabupaten Maros.

\section{HASIL PENELITIAN DAN PEMBAHASAN}

\section{Deskripsi Kondisi Awal}

Hampir semua pendidik ditemukan kurang memahami aspek yang ada dalam konsep sistem penilaian dan penerapannya. Kesalahan umum yang tampak adalah: (1) pendidik belum mampu menentukan KKM, (2) pendidik belum mampu menggunakan kata kerja operasional (KKO) dengan tepat pada perumusan soal, (3) pendidik belum mampu menentukan penilaian pengetahuan, sikap dan keterampilan, (4) pendidik belum mampu menentukan interval predikat kemampuan peserta didik, dan (5) pendidik belum 


\section{Efektifitas Anti Inflamasi Daun Mangga (Mangifera Indica) Terhadap Luka Bakar Derajat Dua}

mampu membuat deskripsi hasil penilaian sikap (spiritual dan sosial), pengetahuan dan keterampilan dengan tepat. Dalam kaitannya dengan implementasi sistem penilaian pada K-13, ternyata juga ditemukan beberapa kelemahan pendidik, yaitu kurang menggunakan rubrik atau pedoman penskoran dalam menentukan atau memerikasi hasil belajar peserta didik, yang akibatnya ada keceenrungan subjektivitas dalam menentukan nilai hasil belajar peserta didik. Dengan kondisi awal seperti ini perlu adanya tindakan nyata yang diharapkan mampu meningkatkan kinerja pendidik dalam memehami sistem penilaian K-13 dan implementasinya, yakni berupa workshop.

\section{Deskripsi Siklus I}

\section{Perencanaan}

Perencanaan terdiri atas: (1) melaporkan kegiatan penelitian kepada Kepala Dinas Pendidikan Kabupaten Maros beserta mohon izin penelitian; (2) berkoordinasi dengan Kepala SMP Negeri 4 Bantimurung dan para pendidik untuk menyampaikan izin penelitian dari Kepala Dinas Pendidikan, dengan minta masukan tentang masalah yang ada sekaligus membicarakan tentang masalah teknis, waktu pelaksanaan penelitian dan hal-hal yang terkait dengan penelitian dan atau workshop yang dilaksanakan; (3) memberikan pengarahan tentang workshop sistem penilaian hasil pembelajaran; (4) mengelompokkan pendidik berdasarkan Mata Pelajaran; (5) menelaah konsep penilaian hasil belajar yang mendekati kondisi mata pelajaran; (6) mendiskusikan konsep penilaian dan presentasi kelompok, (7) menghasilkan system penilaian final.

Di samping perencanaan umum, dilakukan juga perencanaan teknis pelaksanaan kegiatan seperti: (1) mengumpulkan pendidik melalui undangan kepala sekolah; (2) menyusun jadual workshop: hari, tanggal, jam dan tempat; (3) menyiapkan materi workshop; pengarahan kepala sekolah, pemaparan materi sistem penilaian hasil pembelajaran dari ahli yang membidangi; (4) menyuruh pendidik membawa bahanbahan seperti; soal-soal, hasil pekerjanaan peserta didik, hasil pekerjaan peserta didik yang telah diperiksa, rumusan rekomendasi ke wali kelas dan sebagainya; (5) pengelompokan pendidik menurut mata pelajarannya; (6) menyiapkan konsumsi untuk workshop, dan (7) menyuruh pendidik membawa laptop (minimal terdapat 4 laptop dan 1 LCD).

\section{Pelaksanaan Tindakan}

Pada tahap ini dilakukan beberapa langkah, yakni: (1) absensi peserta; (2) pengarahan kepala sekolah; (3) penjelasan umum kepada seluruh peserta; (4) peserta dikelompokkan sesuai mata pelajaran; (5) pendidik mengkaji Peraturan Menteri Pendidikan dan Kebudayaan Republik Indonesia yang terkait dengan standar penilaian; (6) peneliti menyajikan materi tentang system penilaian berdasarkan kurikulum 2013, (7) Peneliti memberikan kesempatan kepada pendidik untuk mengajukan pertanyaan tentang hal-hal yang kurang atau belum dipahami dengan baik, (8). Peneliti memberikan tugas berupa LK kepada pendidik sesuai dengan mata pelajarannya, (9), presentasi visual sesuai dengan LK yang dikerjakan secara berkelompok mata pelajaran. 


\section{Hasil Observasi}

Pada tahap ini dilakukan pengamatan terhadap pelaksanaan tindakan, yaitu menitikberatkan pada kompetensi pendidik dalam membuat perangkat penilaian hasil pembelajaran sebagai akibat diterapkan workshop. Tujuan dilaksanakan pengamatan adalah untuk mengetahui kegiatan yang mana patut dipertahankan, diperbaiki, atau dihilangkan sehingga kegiatan pembinaan melalui workshop benar-benar berjalan sesuai dengan tujuan yang ada dan mampu meningkatkan kinerja peserta dalam memahi sistem penilaian pada K-2013.

Kegiatan peserta juga diobservasi, baik menyangkut kesiapan mental dan fisik pendidik, kesiapan bahan-bahan yang dibawa pendidik pada waktu workshop, kehadiran pendidik, kesiapan laptop, kualitas sistem penilaian hasil pembelajaran, dan respon pendidik. Dari hasil pengamatan terhadap aktivitas peserta dengan menggunakan lembar observasi yang telah disiapkan, diperoleh data sebagai berikut.

Tabel 1. Rangkuman Hasil Observasi tentang Kesiapan Pendidik dalam Mengikuti

Workshop pada Siklus I

\begin{tabular}{|c|c|c|c|c|c|c|c|c|}
\hline & \multicolumn{8}{|c|}{ Aspek yang Diamati } \\
\hline & \multicolumn{2}{|c|}{$\begin{array}{c}\text { Kesiapan } \\
\text { mental dan } \\
\text { fisik pendidik }\end{array}$} & \multicolumn{2}{|c|}{$\begin{array}{c}\text { Kesiapan } \\
\text { bahan }\end{array}$} & \multicolumn{2}{|c|}{$\begin{array}{c}\text { Kehadiran } \\
\text { Pendidik }\end{array}$} & \multicolumn{2}{|c|}{$\begin{array}{c}\text { Kesiapan } \\
\text { Laptop }\end{array}$} \\
\hline & $\mathbf{S}$ & TS & $\mathbf{S}$ & TS & $\mathbf{H}$ & TH & $\mathbf{S}$ & TS \\
\hline Jumlah & 27 & 9 & 24 & 12 & 33 & 3 & 6 & 30 \\
\hline $\begin{array}{c}\text { Persentase } \\
(\%)\end{array}$ & 75,00 & 25,00 & 66,67 & $\mathbf{3 3 , 3 3}$ & 91.67 & 8,33 & 16,67 & 83,33 \\
\hline $\begin{array}{l}\text { Pencapaian } \\
\text { indikator } \\
\text { keberhasilan }\end{array}$ & \multicolumn{2}{|c|}{ Belum tercapai } & \multicolumn{2}{|c|}{$\begin{array}{l}\text { Belum } \\
\text { tercapai }\end{array}$} & \multicolumn{2}{|c|}{ Sudah tercapai } & \multicolumn{2}{|c|}{ Belum tercapai } \\
\hline
\end{tabular}

Keterangan:

$$
\begin{array}{llll}
\mathrm{S} & =\text { siap } & \mathrm{H} & =\text { hadir } \\
\mathrm{TS} & =\text { tidak siap } & \mathrm{TH} & =\text { tidak hadir }
\end{array}
$$

Berdasarkan Tabel 1, tampaknya kesiapan pendidik dalam mengikuti workshop belum memenuhi kriteria keberhasilan untuk semua aspek. Dapat dikatakan bahwa penelitian ini menunjukkan keberhasilan melalui kegiatan workshop yang digambarkan pada grafik berikut: 


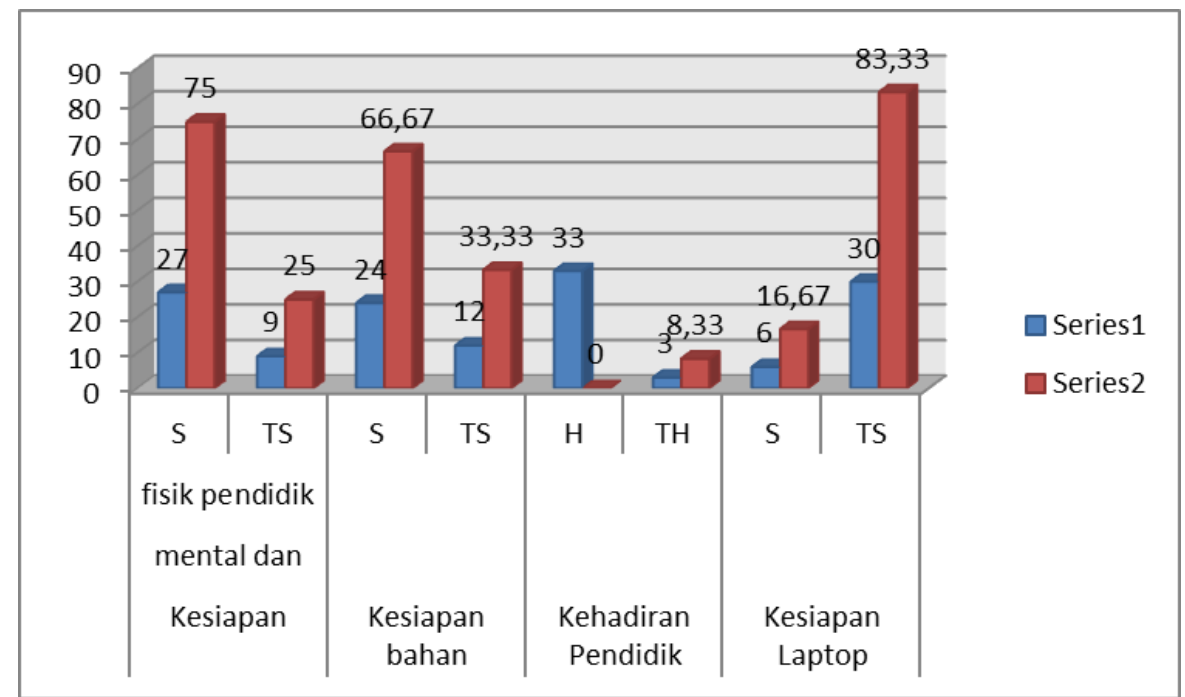

Gambar 1. Grafik kriteria keberhasilan untuk semua aspek Siklus I

Dari hasil evaluasi terhadap penyusunan sistem penilaian yang dibuat oleh 36 orang pendidik, setelah diadakan workshop pada siklus I diperoleh kinerja pendidik dalam membuat penilaian hasil belajar K-2013 seperti tampak pada Tabel 2 berikut:

Tabel 2. Rangkuman Hasil Penilaian Pemahaman Pendidik tentang sistem penilaian Kurikulum 2013 pada Siklus I (Pertama)

\begin{tabular}{|c|c|c|c|c|c|c|c|c|c|}
\hline \multirow{3}{*}{ No } & \multirow{3}{*}{ Aspek yang Dinilai } & \multicolumn{8}{|c|}{ Skor } \\
\hline & & \multicolumn{2}{|c|}{1} & \multicolumn{2}{|c|}{2} & \multicolumn{2}{|c|}{3} & \multicolumn{2}{|c|}{4} \\
\hline & & Jml & $\%$ & $\mathbf{J m l}$ & $\%$ & $\mathbf{J m l}$ & $\%$ & $\mathbf{J m l}$ & $\%$ \\
\hline 1. & $\begin{array}{l}\text { Pemahaman tentang } \\
\text { penilaian sikap }\end{array}$ & 1 & 2,78 & 3 & 8,33 & 17 & 47,22 & 15 & 41,67 \\
\hline 2. & $\begin{array}{l}\text { Pemahaman tentang } \\
\text { penilaian pengetahuan }\end{array}$ & 0 & 0,00 & 8 & 22,22 & 23 & 63,89 & 5 & 13,89 \\
\hline 3. & $\begin{array}{l}\text { Pemahaman tentang } \\
\text { penilaian keterampilan }\end{array}$ & 1 & 2,78 & 13 & 36,11 & 19 & 54,78 & 3 & 8,33 \\
\hline 4. & $\begin{array}{l}\text { Pemahaman tentang } \\
\text { penentuan KKM }\end{array}$ & 4 & 11,11 & 15 & 41,67 & 15 & 41,67 & 2 & 5,56 \\
\hline 5 & $\begin{array}{l}\text { Pemahaman tentang } \\
\text { penentuan interval } \\
\text { predikat }\end{array}$ & 7 & 19,44 & 11 & 30,56 & 17 & 47,22 & 1 & 2,78 \\
\hline 6. & $\begin{array}{l}\text { Pemahaman tentang } \\
\text { rumusan deskripsi sikap }\end{array}$ & 9 & 25,00 & 16 & 44,44 & 10 & 27,78 & 1 & 2,78 \\
\hline 7. & $\begin{array}{l}\text { Pemahaman tentang } \\
\text { rumusan deskripsi } \\
\text { pengetahuan }\end{array}$ & 7 & 19,44 & 17 & 47,22 & 11 & 30,56 & 1 & 2,78 \\
\hline 8. & $\begin{array}{l}\text { Pemahaman tentang } \\
\text { rumusan deskripsi } \\
\text { keterampilan }\end{array}$ & 7 & 19,44 & 19 & 52,78 & 7 & 19,44 & 3 & 8,33 \\
\hline 9. & $\begin{array}{l}\text { Pemahaman tentang } \\
\text { penentun nilai rapor }\end{array}$ & 3 & 8,33 & 12 & 33,33 & 15 & 41,67 & 6 & 16,67 \\
\hline
\end{tabular}




\begin{tabular}{|l|l|l|l|l|l|l|l|l|l|}
\hline & /laporan & & & & & & & & \\
\hline 10. & $\begin{array}{l}\text { Pemahaman tentang } \\
\text { rubrik/pedoman } \\
\text { penilaian. }\end{array}$ & 4 & 11,11 & 10 & 27,78 & 16 & 44,44 & 6 & 16,67 \\
\hline
\end{tabular}

Keterangan:

4 = sangat baik

$3=$ baik

$$
\begin{aligned}
& 2=\text { cukup } \\
& 1=\text { tidak baik }
\end{aligned}
$$

Berdasarkan deskripsi pada Tabel 1 dan 2 tampaknya kinerja pendidik membuat sistem penilaian pembelajaran para pendidik belum memenuhi indikator kinerja yang telah ditetapkan pada semua aspek, baik menyangkut kesiapan maupun kinerja membuat sistem penilaian pembelajaran.

\section{Refleksi}

Setelah diadakan refleksi terhadap hasil yang diperoleh pada siklus I, diputuskan untuk memperbaiki dari segi kegiatan workshop terutama memperjelas tentang aspekaspek yang belum sesuai dengan indikator kinerja yang telah ditetapkan. Dari hasil tersebut tampaknya secara umum pemahaman pendidik tentang penentuan KKM masih kurang, yaitu terdapat 19 pendidik dari 36 orang atau 52,78\% yang tergolong dalam kategori kurang baik, pemahaman pendidik tentang penentuan interval predikat masih kurang dimana terdapat 18 pendidik dari 36 orang atau 50,00\% yang tergolong dalam kategori kurang baik, pemahaman pendidik tentang runusan deskripsi sikap masih kurang dimana terdapat 25 pendidik dari 36 orang atau $69,44 \%$ yang tergolong dalam kategori kurang baik, pemahaman pendidik tentang rumusan deskripsi pengetahuan masih kurang dimana terdapat 24 pendidik dari 36 orang atau 66,67\% yang tergolong dalam kategori kurang baik, pemahaman pendidik tentang rumusan deskripsi keterampilan masih kurang dimana terdapat 26 pendidik dari 36 orang atau 72,22\% yang tergolong dalam kategori kurang baik, dan pemahaman pendidik tentang penentuan nilai raport masih kurang dimana terdapat 15 pendidik dari 36 orang atau $41,67 \%$ yang tergolong dalam kategori kurang baik.

Terkait dengan kesiapan pendidik, ditemukan bahwa pendidik belum menyadari pentingnya penyusunan sistem penilaian pembelajaran. Selain itu, pendidik belum memiliki kisi-kisi soal yang lengkap, pedoman penilaian/ rubrik penilaian. Mengenai kehadiran, tampak pendidik yang tidak hadir disebabkan karena ada kepentingan diklat lain. Terkait dengan kesiapan laptop, pendidik kebanyakan tidak memiliki, alternatif solusinya adalah menggunakan labtop atau komputer yang ada di sekolah. Berdasarkan hasil refleksi tersebut, diputuskan untuk memantapkan kegiatan pembinaan yang lebih memfokuskan pada aspek-aspek yang belum memenuhi indikator kinerja yang telah ditetapkan.

Dari masalah tersebut, diputuskan untuk memperbaiki beberapa langkah dalam siklus I, yakni memfokuskan pada penjelasan tentang komponen panilaian hasil pembelajaran peserta didik yang belum mencapai kategori baik atau sangat baik. Langkah-langkah ini dijalankan pada siklus II dengan tetap mempertahankan kegiatan 


\section{Efektifitas Anti Inflamasi Daun Mangga (Mangifera Indica) Terhadap Luka Bakar Derajat Dua}

yang lain yang sudah dianggap baik. Untuk meningkatkan kesiapan pendidik, peneliti memberikan kesadaran bahwa betapa penting perencanaan penilaian hasil pembelajaran yang dibuat pendidik. Mengenai alternatif untuk menambah laptop, diputuskan untuk memanfaatkan komputer (PC) yang ada di sekolah.

\section{Deskripsi Hasil Siklus II (Kedua)}

Pada siklus II, langkah-langkah yang diambil sesuai dengan refleksi hasil siklus I mengikuti langkah-langkah seperti siklus I dengan memfokuskan pada penjelasan aspek-aspek yang belum dipahami pendidik dalam membuat sistem penilaian hasil pembelajaran lebih menitikberatkan pada aspek pembimbingan secara individu. Dari 36 orang pendidik semua dilibatkan dalam siklus II untuk memperdalam pengetahuan tentang penyusunan sistem penilaian hasil pembelajaran. Setelah siklus II dijalankan yang mengacu pada refleksi dan pemecahan masalah pada siklus I diperoleh data tentang seperti tampak pada Tabel 3 berikut.

Tabel 3. Rangkuman Hasil Observasi tentang Kesiapan Pendidik dalam Mengikuti Workshop pada Siklus II

\begin{tabular}{|c|c|c|c|c|c|c|c|c|}
\hline & \multicolumn{8}{|c|}{ Aspek yang Diamati } \\
\hline & \multicolumn{2}{|c|}{$\begin{array}{c}\text { Kesiapan } \\
\text { mental dan } \\
\text { fisik pendidik }\end{array}$} & \multicolumn{2}{|c|}{$\begin{array}{c}\text { Kesiapan } \\
\text { bahan }\end{array}$} & \multicolumn{2}{|c|}{$\begin{array}{c}\text { Kehadiran } \\
\text { Pendidik }\end{array}$} & \multicolumn{2}{|c|}{$\begin{array}{c}\text { Kesiapan } \\
\text { Laptop }\end{array}$} \\
\hline & $\mathbf{S}$ & TS & $\mathbf{S}$ & TS & $\mathbf{H}$ & TH & $\mathbf{S}$ & TS \\
\hline Jumlah & 34 & 2 & 32 & 4 & 36 & 0 & 31 & 5 \\
\hline Persentase (\%) & 94,44 & 5,56 & 88,89 & 11,11 & 100 & 0,00 & 86,11 & 13,89 \\
\hline $\begin{array}{l}\text { Pencapaian } \\
\text { Indikator } \\
\text { Keberhasilan }\end{array}$ & \multicolumn{2}{|c|}{ Tercapai } & \multicolumn{2}{|c|}{ Tercapai } & \multicolumn{2}{|c|}{ Tercapai } & \multicolumn{2}{|c|}{ Tercapai } \\
\hline
\end{tabular}

Keterangan:

$\begin{array}{llll}\mathrm{S} & =\text { siap } & \mathrm{H} & =\text { hadir } \\ \mathrm{TS} & =\text { tidak siap } & \mathrm{TH} & =\text { tidak hadir }\end{array}$

Berdasarkan Tabel 3 tampaknya kesiapan pendidik dalam mengikuti workshop belum telah memenuhi kriteria keberhasilan untuk semua aspek. Namun belum sepenuhnya tercapai seratus persen.

Dapat dikatakan bahwa penelitian ini menunjukkan keberhasilan melalui kegiatan workshop yang digambarkan pada grafik berikut: 


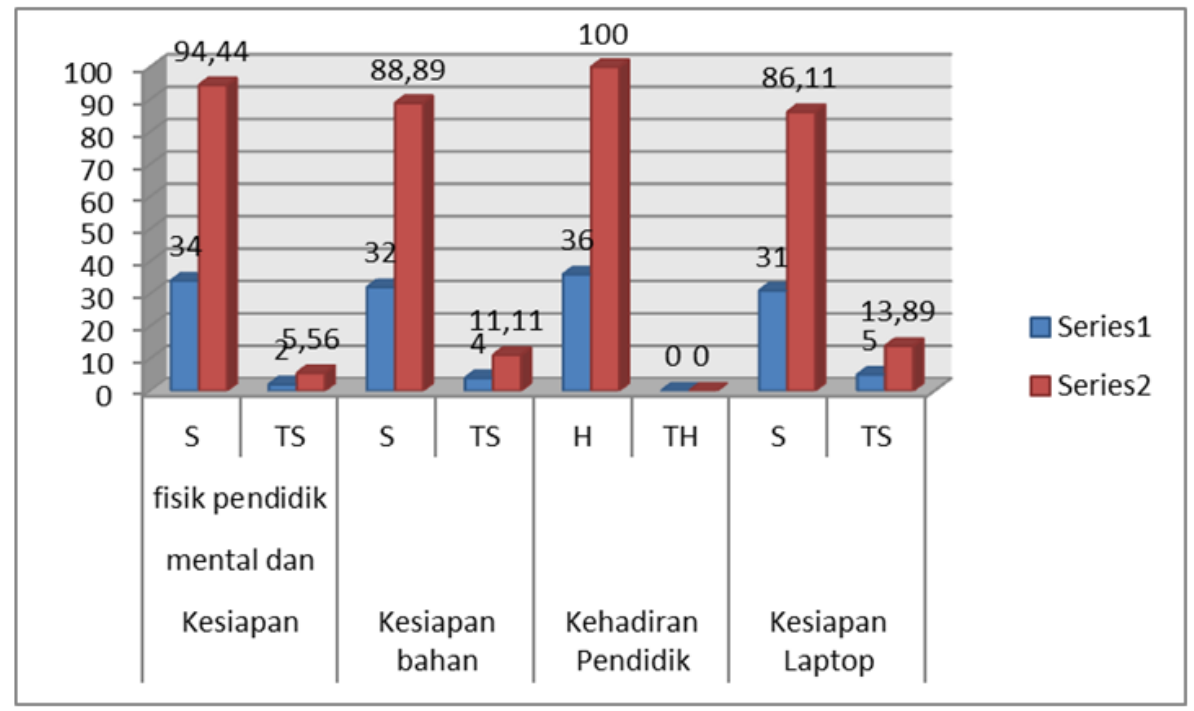

Gambar 2. Grafik kriteria keberhasilan untuk semua aspek Siklus II

Dari hasil evaluasi terhadap penyusunan sistem penilaian hasil pembelajaran yang dibuat oleh 36 orang pendidik setelah diadakan workshop pada siklus II, diperoleh kinerja pendidik dalam membuat sistem penilaian hasil pembelajaran sebagai berikut:

Tabel 4. Rangkuman Hasil Penilaian Kompetensi Pendidik dalam Membuat sistem penilaian hasil pembelajaran pada Siklus II (Kedua)

\begin{tabular}{|c|l|c|c|c|c|c|c|c|c|}
\hline \multirow{2}{*}{ No } & \multirow{2}{*}{ Aspek Yang Dinilai } & \multicolumn{7}{|c|}{$\mathbf{1}$} & \multicolumn{2}{|c|}{$\mathbf{2}$} & \multicolumn{2}{|c|}{$\mathbf{3}$} & \multicolumn{2}{|c|}{$\mathbf{4}$} \\
\cline { 2 - 10 } & & $\mathbf{J m l}$ & $\mathbf{\%}$ & $\mathbf{J m l}$ & $\mathbf{\%}$ & $\mathbf{J m l}$ & $\mathbf{\%}$ & $\mathbf{J m l}$ & $\mathbf{\%}$ \\
\hline 1. & $\begin{array}{l}\text { Pemahaman tentang } \\
\text { penilaian sikap }\end{array}$ & 0 & 0,00 & 1 & 2,78 & 16 & 44,44 & 19 & 52,78 \\
\hline 2. & $\begin{array}{l}\text { Pemahaman tentang } \\
\text { penilaian } \\
\text { pengetahuan }\end{array}$ & 0 & 0,00 & 3 & 8,33 & 23 & 63,89 & 10 & 27,78 \\
\hline 3. & $\begin{array}{l}\text { Pemahaman tentang } \\
\text { penilaian } \\
\text { keterampilan }\end{array}$ & 0 & 0,00 & 4 & 11,11 & 25 & 69,44 & 7 & 19,44 \\
\hline 4. & $\begin{array}{l}\text { Pemahaman tentang } \\
\text { penentuan KKM }\end{array}$ & 0 & 0,00 & 5 & 13,89 & 20 & 55,56 & 11 & 30,56 \\
\hline 5. & $\begin{array}{l}\text { Pemahaman tentang } \\
\text { penentuan interval } \\
\text { predikat }\end{array}$ & 0 & 0,00 & 6 & 16,67 & 20 & 55,56 & 10 & 27,78 \\
\hline 6. & $\begin{array}{l}\text { Pemahaman tentang } \\
\text { rumusan deskripsi } \\
\text { sikap }\end{array}$ & 1 & 2,78 & 4 & 11,11 & 22 & 61,11 & 9 & 25,00 \\
\hline 7. & $\begin{array}{l}\text { Pemahaman tentang } \\
\text { rumusan deskripsi } \\
\text { pengetahuan }\end{array}$ & 1 & 2,78 & 8 & 22,22 & 20 & 55,56 & 7 & 19,44 \\
\hline
\end{tabular}



Derajat Dua

\begin{tabular}{|c|l|c|c|c|c|c|c|c|c|}
\hline 8. & $\begin{array}{l}\text { Pemahaman tentang } \\
\text { rumusan deskripsi } \\
\text { keterampilan }\end{array}$ & 0 & 0,00 & 8 & 22,22 & 18 & 50,00 & 10 & 27,78 \\
\hline 9. & $\begin{array}{l}\text { Pemahaman tentang } \\
\text { penentun nilai rapor } \\
\text { /laporan }\end{array}$ & 0 & 0,00 & 5 & 13,89 & 23 & 63,89 & 8 & 22,22 \\
\hline 10. & $\begin{array}{l}\text { Pemahaman tentang } \\
\text { rubrik/pedoman } \\
\text { penilaian. }\end{array}$ & 0 & 0,00 & 6 & 16,67 & 15 & 41,67 & 15 & 41,67 \\
\hline
\end{tabular}

Keterangan:

4 = sangat baik $\quad 2=$ cukup

$3=$ baik $\quad 1=$ tidak baik

Berdasarkan deskripsi pada Tabel 3 dan 4 tampaknya kinerja pendidik membuat sistem penilaian hasil pembelajaran Para pendidik sudah memenuhi indikator kinerja yang telah ditetapkan pada semua aspek, baik menyangkut kesiapan maupun kinerja membuat sistem penilaian hasil sistem penilaian hasil pembelajaran. Dengan hasil seperti itu, berarti tindakan yang diberikan efektif dalam meningkatkan kinerja pendidik dalam membuat sistem penilaian hasil pembelajaran.

\section{Respon Pendidik Terhadap Penyusunan Sistem Penilaian Hasil Pembelajaran Melalui Workshop}

Penilaian ini penting dilakukan untuk memperoleh gambaran tentang respon pendidik terhadap kegiatan workshop yang telah diterapkan dalam membuat sistem penilaian hasil pembelajaran. Bila pendidik merespon positif terhadap kegiatan tersebut, maka kegiatan tersebut perlu dilanjutkan dalam kegiatan-kegiatan yang lain.

Untuk menentukan klasifikasi respon pendidik terhadap kegiatan membuat sistem penilaian hasil pembelajaran melalui workshop terlebih dahulu dihitung mean ideal (Mi) dan standar deviasi ideal (SDi). $\mathrm{Mi}=1 / 2$ (skor maksimum + skor minimum), dimana skor maskimum,yaitu 95 , sedangkan skor minimum, yaitu 45. Dengan demikian $\mathrm{Mi}=1 / 2(95+45)=70$, dan $\mathrm{SDi}=1 / 6($ skor maksimum - skor minimum $)=1 / 6$ $(95-45)=8,33$ berdasarkan hasil ini dibuat klasifikasi sebagai berikut.
a. $\quad \mathrm{x} \geq \mathrm{Mi}+1,5 \mathrm{SDi} \rightarrow$ sangat baik/ sangat positif
b. $\mathrm{Mi}+0,5 \mathrm{SDi} \leq \mathrm{x}<\mathrm{Mi}+1,5 \mathrm{SDi} \rightarrow$ baik/ positif
c. $\mathrm{Mi}-0,5 \mathrm{SDi} \leq \mathrm{x}<\mathrm{Mi}+0,5 \mathrm{SDi} \rightarrow$ cukup baik/ cukup positif
d. $\mathrm{Mi}-1,5 \mathrm{SDi} \leq \mathrm{x}<\mathrm{Mi}-0,5 \mathrm{SDi} \rightarrow$ kurang baik/ kurang positif
e. $\mathrm{x}<\mathrm{Mi}-1,5 \mathrm{SDi} \rightarrow$ sangat kurang baik/ sangat kurang positif

Dengan memasukkan Mi dan SDi diperoleh:
a. $\quad x \geq 82,50 \rightarrow$ sangat baik/ sangat positif
b. $74,17 \leq \mathrm{x}<80,50 \rightarrow$ baik/ positif
c. $65,83 \leq \mathrm{x}<74,17 \rightarrow$ cukup baik/cukup positif
d. $57,51 \leq \mathrm{x}<65,83 \rightarrow$ kurang baik/kurang positif
e. $x<57,51 \rightarrow$ sangat kurang baik/ sangat kurang positif 
Rata-rata skor respon pendidik terhadap kegiatan membuat sistem penilaian hasil pembelajaran dengan melalui workshop adalah 77,03 atau dengan kategori baik/positif dan standar deviasi sebesar 8,33. Bila dicocokkan dengan klasifikasi di atas, respon pendidik tergolong sangat positif. Dengan demikian kegiatan workshop membuat sistem penilaian hasil pembelajaran mendapat respon yang sangat positif dari pendidik kelas VII sampai dengan pendidik kelas IX di SMP Negeri 4 Bantimurung. Oleh karena itu, penerapannya perlu dilanjutkan dalam kegiatan-kegiatan yang lain.

\section{Pembahasan Hasil Penelitian}

Berdasarkan analisis dan pembahasan seperti yang telah dipaparkan pada bagian sebelumnya, maka dapat disimpulkan bahwa terjadi peningkatan aktivitas peserta dalam kegiatan workshop tentang sistem penilaian hasil pembelajaran bagi pendidik di SMP Negeri 4 Bantimurung Kabupaten Maros. Di samping itu juga, terjadi peningkatan kinerja pendidik dalam membuat sistem penilaian hasil pembelajaran melalui workshop di SMP Negeri 4 Bantimurung Kabupaten Maros dari siklus I ke siklus II pada masingmasing aspek dengan target ketercapaian sesuai dengan kriteria yang ditetapkan. Dengan demikian dapat disimpulkan bahwa melalui workshop dapat meningkatkan kinerja pendidik dalam membuat sistem penilaian hasil pembelajaran pendidik di SMP Negeri 4 Bantimurung Kabupaten Maros.

Keberhasilan tindakan ini disebabkan oleh pemahaman secara menyeluruh tentang sistem penilaian. Dengan pemahaman yang baik, maka sistem penilaian hasil pembelajaran dapat disusun dengan baik. Mengoptimalkan pemahaman pendidik terhadap sistem penilaian hasil pembelajaran melalui pembinaan intensif dalam bentuk penyelenggaraan workshop menunjuk pada metode kooperatif konsultatif dimana diharapkan para pendidik berdiskusi, bekerja sama dan berkonsultasi secara aktif. Aktivitas ini akan sangat membantu mereka dalam memahami konsep-konsep dasar penyusunan sistem penilaian hasil pembelajaran serta pada akhirnya nanti mereka mampu membuat sistem penilaian hasil pembelajaran dengan baik dan benar.

Dalam kaitannya dengan pembinaan melalui workshop, maka penelitian ini juga sesuai dengan apa yang dikatakan Amstrong (1990: 209) bahwa tujuan workshop adalah untuk memperoleh tingkat kinerja yang diperlukan dalam pekerjaan mereka dengan cepat dan ekonomis dan mengembangkan kinerja-kinerja yang ada sehingga prestasi mereka pada tugas yang sekarang ditingkatkan dan mereka dipersiapkan untuk menerima tanggung jawab yang lebih besar di masa yang akan datang. Peserta didiknto (1989: 139) mengatakan workshop bertujuan untuk memperoleh nilai tambah seseorang yang bersangkutan, terutama yang berhubungan dengan meningkatnya dan berkembangnya pengetahuan, sikap, dan keterampilan yang bersangkutan. Workshop dimaksudkan untuk mempertinggi kinerja dengan mengembangkan cara-cara berpikir dan bertindak yang tepat serta pengetahuan tentang tugas pekerjaan termasuk tugas dalam melaksanakan evaluasi diri (As'ad, 1987: 64).

Dari paparan di atas, menunjukkan bahwa peningkatan kompetensi pendidik melalui kegiatan workshop yang lebih menekankan pada metode kolaboratif konsultatif akan memberikan kesempatan sharing antara satu pendidik dengan pendidik lain. 


\section{Efektifitas Anti Inflamasi Daun Mangga (Mangifera Indica) Terhadap Luka Bakar Derajat Dua}

Dengan demikian, pemahaman terhadap sistem penilaian hasil pembelajaran dapat ditingkatkan baik dalam teoretisnya maupun implementasinya.

\section{KESIMPULAN}

Terjadi peningkatan kesiapan peserta dalam kegiatan workshop di SMP Negeri 4 Bantimurung Kabupaten Maros. Di samping itu juga, terjadi peningkatan kinerja atau pemahaman pendidik dengan kategori minimal baik dalam membuat sistem penilaian hasil pembelajaran melalui pembinaan berupa workshop di SMP Negeri 4 Bantimurung Kabupaten Maros, dari siklus I ke siklus II dan mencapai rata-rata 85,28\%. Nilai ratarata persentase dengan kategori minimal baik telah melampaui target minimal yang telah ditetapkan yakni $85 \%$, artinya $85 \%$ pendidik telah efektif dalam membuat sistem penilaian hasil pembelajaran pada masing-masing aspek. Dengan demikian dapat disimpulkan bahwa melalui workshop dapat meningkatkan kinerja pendidik dalam membuat sistem penilaian hasil pembelajaran di SMP Negeri 4 Bantimurung, Kabupaten Maros. Pendidik juga memberikan respon baik/ positif terhadap kegiatan penyusunan sistem penilaian hasil pembelajaran melalui workshop dengan rata-rata penilaian responden (pendidik) yakni 77,03. Dengan demikian kegiatan workshop memberikan dampak positif terhadap kinerja pendidik dalam membuat sistem penilaian hasil pembelajaran.

\section{DAFTAR PUSTAKA}

Badudu, J.S. 1988. Kamus Besar Bahasa Indonesia. Jakarta : Gramedia.

Friedenberg, Lisa. 1995. Psychological Testing: Design, Analysis, and Use. Boston: Allyn and Bacon.

Gulo, 2008. Strategi Belajar Mengajar. Jakarta: Gramedia Widia sarana Indonesia.

Mathis dan Jackson. 2002. Manajemen Sumber Daya Manusia. Jakarta: Salemba Empat Moejiono,2006.Prosedur Belajar Mengajar. Bandung: Rosdakarya

Nurkancana, Wayan dan Sunartana. 1992. Evaluasi Hasil Belajar. Surabaya: Usaha Nasional.

Pannen Dan Sekarwinahya. 1994. Kurikulum Berbasis Kompetensi. Konsep; Karakteristik dan Implementasi. Bandung : Remaja Rosdakarya

Prokton and W.M. Thornton. 1983. Latihan Kerja Buku Pegangan Bagi Para Manager. Jakarta: Bina Aksara

Purwanto, M Ngalim. 1984. Prinsip-prinsip dan Teknik Evaluasi Pengajaran. Bandung : Remaja Rosda Karya 
Anisa (2019)

Simamora, Henry. 1995. Manajemen Sumber Daya Manusia. Yogyakarta : STIE YPKN.

Soekamto Dan Winata, P. 1997. Strategi Belajar Mengajar. Bandung : Pustaka Setia

Tim Penyusun Kamus Pusat Pembinaan dan Pengembangan Bahasa. 1989. Kamus Besar Bahasa Indonesia. Jakarta: Balai Pustaka. 